\title{
ABOUT THE SIGNIFICANCE OF ENERGY SAVING PROGRAM. ECOLOGICAL ASPECT
}

\author{
Voinov O.P., Doctor of Engineering, Professor, \\ ORCID: 0000-0001-7548-4212 \\ Elkin Yu.G., Ph.D., Associate Professor, \\ Odessa State Academy of Civil Engineering and Architecture \\ yrik29@gmail.com, ORCID: 0000-0001-7677-377X
}

\begin{abstract}
The population of the Earth is growing with acceleration. Their needs are growing. Industry is developing intensively. The level of its energy efficiency is low. The harmful effects of production on the environment are increasing, especially the impact of power engineering, which is successfully developing regardless of the conditions in the state. Humanity has faced the problem of protecting and saving the natural environment and humanity from the harmful effects of industry, primarily from the growing impact of power engineering. The aim and tasks of the problem is to analyze the current environmental situation under the influence of global power engineering and ways to solve its tasks. In the power engineering objects on organic fuels the greatest damage to the natural environment is caused by boiler sets. The structure of the fuel and energy balance of power engineering in Ukraine is complex. In the depths of Ukraine, 95\% of the energy is in solid fuel. In the fuel balance, the share of very expensive imported liquid and gaseous fuels is very large; it complicates the economic situation in the power engineering sector and in the state as a whole. The complex problem of the normalization of the structure of the fuel balance of the domestic power engineering has been formed. The stock of existing boilers is worn out; it needs an immediate full renovation. This is a complex problem too: there is no developed own boiler building, the available resources are insufficient, there is no time fund. The problem of saving the natural environment worried the world community. Important decisions of the Kyoto Protocol and the Paris Climate Conference were taken. The desire to improve the environmental friendliness and energy efficiency of the applied technologies led to the development of the concept and energy saving program, as a key direction for the development of modern industry. In Ukraine, an energy saving program was accepted in 1994. The implementation of the energy saving program allows combining the energy efficiency of industry with environmental friendliness. Subject of advanced research in the field of world power engineering should be focused on ensuring the tasks of the energy saving program and improving the efficiency of environmental activities of the society.
\end{abstract}

Keywords: energy saving, energy efficiency, power engineering, environmental friendliness, environmental protection.

Introduction. After the industrial period of its development, world production since the mid20th century has been developing stagnantly, without acceleration. It provides the growing needs of the world's population, whose number is increasing. The character and tempo of development of different industry branches in different countries are different and reflect the influence of many different global and local factors and conditions.

One of the industry branches is developing stably, almost independently of the environment. We are talking about power engineering - the most important of the industry branches, independently of the scale factor and environmental conditions. This is explained by the unique properties of power engineering: its products - electricity and heat - are necessary for the existence of people, for their normal housing and communal conditions and for work.

Modern world power engineering includes two parts: stationary one and transport one. In turn, stationary power engineering is represented by organic fuel's power engineering and nuclear 
fuel's power engineering. Power engineering using organic fuel is a basic part in the history of the industry and its main part in volume of generated energy. Power engineering using organic fuel is for further consideration.

In the current period of development of world production, among the problems facing humanity, the most acute is the problem of protecting and saving the natural environment (NE) from the growing, extremely dangerous, harmful effects of developing world production.

Analysis of recent researches and publications. As you know, the intensity of the harmful effects of different industry branches on NE is not the same. The most aggressive, multilateral, impact is exerted by world power engineering. At the same time, its effect is extremely dangerous for NE, for inanimate and living nature, including man. This problem is in the center of attention of power engineering experts [1-4].

In the world, a powerful energetic base of production was created during the industrialization period. In the current stagnation period, the capacity building of the global power engineering sector continues.

The growing changes in climate and NE, fixed by science and becoming visible, alarmed mankind, forced them to focus their attention and efforts on counteracting the impact of power engineering on the life and fate of nature and future generations of humanity.

In these increasingly complicated conditions, the global problem of NE saving from the growing harmful effects of the developing world power engineering has formed and has risen to its full extent.

A scientific assessment of the NE state indicates the occurrence of irreversible, extremely dangerous global climate changes and the state of PS, especially wildlife, that have occurred and are occurring.

Based on the foregoing, there is reason to argue that the problem of NE saving from harmful anthropogenic impacts in general, especially the impact of the power engineering sector, has acquired the status of an urgent leading global problem requiring immediate solution.

The aim and tasks of the problem is to analyze the current environmental situation under the influence of world power engineering and ways to solve its tasks.

Materials and methods of research. It has been established that as part of power facilities, the main source of harmful effects on the NE are boiler plants [5, 6].

The harmful effects of boiler plants (especially those operating on solid fuel) on substations are mainly as follows:

- emission of heat, greenhouse and toxic gases, water vapor, ash particles;

- discharge of heat, solid focal residues, contaminated waters.

Currently, in the world more than $40 \%$ of electricity is generated in power plants burning solid fuels.

The level of harmful effect on NE from the boiler plant depends to a large extent on its design, type and grade of burned fuel, degree of its physical deterioration, its maintenance level, the quality of its operation control process, and the level of technological culture of equipment maintenance. The issues of the need to reduce the emission of nitrogen oxides, sulfur oxides, and ash are in need of increased attention [7].

The performance indicators of the domestic boiler fleet are also associated with the structure of the fuel and energy balance of the industry, since the form and type of fuel determines the result of the technological process of the boiler plant.

According to official figures, in Ukraine in the proven fuel reserves, solid fuel accounts for about $95 \%$. About $2 \%$ - for liquid and about $3 \%$ - for gaseous.

In the structure of the fuel and energy balance of organic fuel power engineering, cheap domestic solid fuel is only about $55 \%$, natural gas is about $40 \%$, fuel oil is about $5 \%$. At the same time, $80 \%$ of the natural gas used is imported, $100 \%$ of fuel oil is imported. The price of imported fuel is prohibitively high compared to the price of domestic fuel.

In the heat balance of domestic power engineering, the share of heat obtained from burning expensive imported fuel is very high. This greatly complicates the economic and organizationaltechnical situation in the fuel and energy complex and in the production sector of the country as a 
whole.

An important, acute, difficult and urgent problem of normalizing the structure of the fuel and energy balance of organic fuels has arisen. The problem has a state level of importance. Its solution should lead to the solution of the existing discrepancy between the needs of the energy industry and the real possibilities of satisfying them. It is necessary to develop and implement at the state level a program of measures to solve the tasks of this problem.

The described circumstances and the changing political and economic situation in the world complicate the task of providing high-quality modern energy supply to a complex of consumers. It is necessary to solve in parallel a set of complex interconnected tasks of a different nature. Some relate to the state of currently used equipment in power plants.

In the Ukraine energy sector, the modern boiler fleet is represented by units, which in their overwhelming number are extremely worn out. The level of technological efficiency of functioning of such units is low, and the degree of their harmful effects on NE is extremely high. The current state of domestic energy needs radical improvement as soon as possible. Its basis should be a complete renovation of the main part of the existing equipment of power plants, primarily the boilers renovation [8].

It is especially necessary to fix on the task of the upcoming full renovation of the vast majority of extremely worn-out boilers operating in the domestic power engineering. This task is difficult for a number of reasons:

- the absence in Ukraine of the necessary own boiler-building production, with the exception of the Monastyrishche machine-building plant, producing a small number of boilers of low power;

- the need to invest very large financial resources in acquiring the necessary boilers on the world market;

- the need for short-term implementation of diverse works complex of a very large volume, without which it is impossible to carry out a complete renovation of the main equipment at numerous energetic objects.

Full renovation of other worn-out equipment of power engineering plants now is also difficult. Therefore, a partial upgrade, preparation for the start of a systematic full upgrade can be considered a really affordable and appropriate way to develop power engineering plants in the near future.

At the same time, there is the reason to argue that the upcoming development of boiler building is a difficult task for the development of domestic engineering, in particular, energetic one [9].

Research results. The growing problem of NE salvation from the harmful effects of global power engineering has aroused extreme concern of the world community, prompted it to search for ways and means to normalize the situation in world production, especially in the global power engineering, in order to reduce the harmful effects on NE, its salvation and saving.

The severity of the problem was reflected, in particular, in documents of global importance: in the 1997 Kyoto Protocol on reducing greenhouse gas emissions and in the 2015 Paris Agreement on Climate: on reducing $\mathrm{CO}_{2}$ in the atmosphere. Nowadays, the world community is set up and focused on decisive actions for the purpose of salvation and saving of NE, inanimate nature, wildlife, including humanity.

The combined focused efforts of the world community to NE protect have led to the formation of a global concept and energy saving program to be implemented by all sectors of world production and the population of all states.

An energy saving program is an activity aimed at the rational use and economical use of energetic resources, which is implemented using technical, economic and legal methods.

It is necessary to provide an integrated approach to energy saving policies at all stages of energy production, transformation and consumption.

The energy saving program, which formally orientates towards a careful attitude to the used energy, actually covers the entire sphere of energy management - energy production, energy transportation and energy use [10].

Energy saving and improving the energy efficiency of equipment are a priority area of the European Union policy, the implementation of which contributes to the creation of a competitive 
and energy-independent economy, reducing the harmful effects on the NE and climate protection.

The activities of the energy saving program can really ensure high efficiency of use on existing equipment, especially on worn-out technical objects.

The value of the energy saving program is of national importance. In Ukraine, the Verkhovna Rada adopted the «Law on Energy Saving» No. 74/94-BP on 01.07.1994, its revision No. 2095-VIII is valid from 23.07.2017.

The control of the energy saving program measures implementation must be of appropriately high quality and must meet its high purpose.

The whole scope of the functioning of the parts of the state mechanism related to the implementation of the energy saving program in Ukraine is greatly complicated by the high degree of equipment wear in the main part of the existing energy generating plants. Its forthcoming full renovation is a task of the state level of importance.

Today, the most important and responsible part of the global community's efforts to NE protect from the harmful effects of power engineering is the real and responsible implementation of a broad energy saving program on a global scale.

The process of energy saving should be understood literally: as the economical use of energy resources - electricity and heat - in all areas of their use. The program of activities should be comprehensively-systemic.

The activities of the energy saving program are clearly oriented ecologically, that is, they have an environmentally friendly creature. They increase the level of environmental efficiency of energy equipment systems that generate, transport and use electricity and heat.

The activities of the energy saving program are able to ensure high efficiency of their use on existing equipment, especially on worn-out technical objects of power engineering.

The current organization of engineering systems use in housing and communal services of settlements needs to be seriously improved. The system of necessary measures of this nature is an essential element of the energy saving program [11].

The control of the energy saving program measures implementation must be of appropriately high quality and must meet its high purpose.

One of the main tasks of energy saving is to minimize the cost of acquiring fuel and energy resources. In addition, it's important the effect of the introduction of energy-saving technologies reducing the load on the NE.

Some modern private energy saving programs are often formal and replace the concept of energy efficiency with the narrower concept of energy saving.

In recent years, an understanding of the responsibility of each citizen for the ecology of the region, country, planet as a whole has grown significantly, but has not become universal yet.

Using the world's traditional energy sources, it is necessary to keep in mind the rapidly escalating fierce competition, which are represented them by the relatively recently emerged alternative energy sources. Among their harmoniously combined properties, one has a decisive positive significance - an unusually high environmental friendliness. Formed by such energy sources, the so-called «green» energetic will rapidly develop and displace power engineering using hydrocarbon energy sources.

The European Union expects to receive about $20 \%$ of electricity generated from alternative sources in 2020 [12].

The foregoing requires striving to increase the level of environmental friendliness of modern traditional power plants, and in them, above all, striving to improve the environmental friendliness of boiler plants.

Within the framework of the energy saving program, work to increase the level of technological efficiency of functioning of existing obsolete equipment of power plants and work to introduce and expand the use of alternative energy sources should be carried out in parallel. In the future, over time, systematically alternative energy sources will supersede worn-out traditional ones and assume the burden of their load. A full upgrade of worn-out power equipment will be successfully completed. The threat level to NE will decrease, but the severity of the problem of its 
protection will remain high. The natural course of this process is obvious, therefore, it receives the full support of the world community.

Modern society should be thoroughly aware of the purpose, idea and content of the energy saving program. The attitude of society towards the implementation of the energy saving program determines the obtained result. Only under this condition, the highly humane, saving for NE and humanity potential environmental capability of the program can be realized.

The education system at all levels, public organizations of various types, the media, experts of various specialties are required to conduct explanatory work among the population, revealing the purpose and content of events, in accordance with the requirements and conditions of the energy saving program, are obliged to bring to the listener and explain the spirit of this program, its unique environmental protection value. It is necessary to simply and clearly show the place of each citizen in the implementation of the program. The result is important, especially the socio-psychological aspect of this activity.

\section{Conclusions:}

1. Widely developed world production has an intense, versatile, continuously increasing harmful effect on the natural environment.

2. Among the problems facing mankind today, the problem of protecting the natural environment from harmful anthropogenic effects has acquired a priority position, utmost acuteness and urgency.

3. The most dangerous manifestation of the harmful effects is the accelerating effect of global warming, due to the functioning of the world energetic complex.

4. The problem facing the mankind in saving the natural environment from the growing formidable danger from the world energetic sector is the main problem of global significance.

5. A set of measures developed in the world to counteract the harmful effects of global power engineering on the environment has allowed us to formulate the concept and problem of energy saving, the particular importance and relevance of which are exacerbated with acceleration.

6. As a means of counteracting the harmful effects of world production, its energetic complex, the problem of increasing the level of environmental efficiency of its facilities has arisen.

7. The main indicator of the degree of productivity of a technical object, including an energy one, is the level of technological efficiency of functioning. In its composition, the main indicator is the level of environmental efficiency. Among the objects of modern power equipment, the lowest environmental friendliness is characteristic of solid fuel boiler plants.

8. High-quality automatic control over the functioning of a technical object is a productive means of maintaining an affordable maximum level of environmental performance.

9. The development of alternative energy sources and their replacement of traditional sources contribute to reducing the level of harmful environmental impact from the world power engineering.

10. The modern world community needs to ensure the rigorous implementation of a set of energy saving programs at work and at home. The quality of its implementation will determine the conditions and quality of life of future generations.

11. A fundamental fact is the conservation entity of the energy saving program. This fact must be brought to an understanding, to the consciousness of every citizen in his childhood.

12. The topic of advanced research in the field of world energy should be focused on ensuring the objectives of the energy saving program and improving the efficiency of environmental activities of the society.

\section{References}

[1] N.M. Fialko, R.O Navrods'ka, G.O. Presich and oth., "Pidvishchennya ekologichnoï efektivnosti kompleksnih teploutilizacijnih sistem kotel'nih ustanovok", Promislova teplotekhnika, Vol. 40, no. 2, pp. 27, 2018.

[2] B.I. Basok, E.T. Bazeev, "Povyshenie energoeffektivnosti ekonomiki Ukrainy - missiya i osnovnoj prioritet razvitiya otechestvennoj energetiki", Promislova teplotekhnika, Vol. 39, 
no. 2, pp. 46, 2017.

[3] V.V. Zhabo, Ohrana okruzhayushchej sredy na TES i AES. Moscow: Energoatomizdat, 2012.

[4] L.A. Rihter, E.P. Volkov, V.N. Pokrovskij, Ohrana vodnogo i vozdushnogo bassejnov TES. Moscow: Energiya, 2001.

[5] A.P. Voinov, S.A. Voinova, "Upravlenie zashchitoj atmosfernogo vozduha ot zagryazneniya energoustanovkami na tverdom toplive", Energetika ta elektrifikaciya, no. 6, pp. 25-28, 2018.

[6] A.P. Voinov, Yu.G. El'kin, "Ob umen'shenii zagryazneniya atmosfery otopitel'nymi kotel'nymi na tverdom toplive", Visnyk ODABA, Odesa, Optimym, vol. 73, pp. 143-149, 2018.

[7] A.P. Voinov, Yu.G. El'kin, "Vysokoeffektivnye zolouloviteli v kotel'nyh ustanovkah. Analitiko-upravlencheskij aspect", Mat. to II Int. scient.-tech. conf. "Actual problems of energy-, resource conservation and ecology», Odesa, ODABA, pp. 8-9, 2018.

[8] A.P. Voinov, S.A. Voinova, "Problematika obnovleniya parka kotlov v Ukraine. Zadachi, upravlenie", Budivnictvo. Nauka. Proekti. Ekonomika, Vol. 1(14), pp. 39-43, 2014.

[9] A.P. Voinov, "Razvitie kotlostroeniya - ostraya problema razvitiya mashinostroeniya $\mathrm{v}$ Ukraine", Energetika ta elektrifikaciya, no. 5, pp. 5-8, 2016.

[10] V.V. Stafievskaya, A.M. Velenteenko, V.A. Frolov, Metody i sredstva energo- i resursosberezheniya. Versiya 1.0. [Elektronnyy resurs]. Rezhim dostupa: http://files.lib.sfukras.ru/ebibl/umkd/10/u_course.pdf. Accessed on: June 2019.

[11] Yu.G. El'kin, A.P. Voinov, "Ispol'zovanie inzhenernyh sistem v zhilishchno-kommunal'nom hozyajstve", Tezi dopov. 75-ï nauk.-tekhn. konf., ODABA 16-17 trav. 2019, Odesa: ODABA, pp. 227, 2019.

[12] O. Gogoladze, ES budet poluchat 35\% energii ot vozobnovlyayemykh istochnikov k 2030 godu. [Elektronnyy resurs]. Rezhim dostupa: https://hightech.fm/2018/01/20/renewableenergy-goals. Accessed on: June 2019.

\section{ПРО ЗНАЧЕННЯ ПРОГРАМИ ЕНЕРГОЗБЕРЕЖЕННЯ. ЕКОЛОГІЧНИЙ АСПЕКТ}

Воінов О. П., д.т.н., професор, ORCID: 0000-0001-7548-4212

Елькін Ю. Г., к.Т.н., доцент, Одеська державна академія будівництва і архітектури yrik29@gmail.com, ORCID: 0000-0001-7677-377X

Анотація. Чисельність населення Землі зростає 3 прискоренням. Його потреби зростають. Інтенсивно розвивається виробництво. Рівень його енергоефективності невисокий. Посилюється шкідливий вплив виробництва на природне середовище, особливо вплив енергетики, яка успішно розвивається, незалежно від умов у державі. Перед людством постала проблема захисту і порятунку природного середовища і людей від шкідливого впливу виробництва, перш за все, від наростаючого впливу енергетики. Метою і завданнями проблеми $\epsilon$ аналіз існуючої екологічної обстановки під впливом світової енергетики і шляхів вирішення поставлених перед нею завдань. В об'єктах енергетики на органічному паливі найбільшої шкоди природному середовищу завдають котельні установки. Структура паливно-енергетичного балансу енергетики України є складною. В надрах України 95\% енергії знаходиться в твердому паливі. У паливному балансі частка вельми дорогого імпортного рідкого і газоподібного палива дуже висока; вона ускладнює економічну обстановку в енергетиці і в державі в цілому. Сформувалася складна проблема нормалізації структури паливного балансу вітчизняної енергетики. Парк діючих котлів зношений, потребує негайного повного оновлення. Це також складна проблема: немає розвиненого власного котлобудування, недостатні наявні ресурси, немає запасу часу. Проблема порятунку природного середовища стурбувала світову громадськість. Були прийняті важливі рішення Кіотського протоколу і Паризької наради з питань клімату. Прагнення до 
підвищення екологічності та енергоефективності застосовуваних технологій зумовили розробку концепції i програми енергозбереження, як ключового напрямку розвитку сучасного виробництва. В Україні програму енергозбереження прийняли в 1994 році. Виконання програми енергозбереження дозволяє поєднувати енергоефективність виробництва 3 екологічністю. Тематика перспективних досліджень в області світової енергетики повинна бути орієнтована на забезпечення завдань програми енергозбереження $\mathrm{i}$ підвищення ефективності природоохоронної діяльності суспільства.

Ключові слова: енергозбереження, енергоефективність, енергетика, екологічність, захист природного середовища.

\title{
О ЗНАЧЕНИИ ПРОГРАММЫ ЭНЕРГОСБЕРЕЖЕНИЯ. ЭКОЛОГИЧЕСКИЙ АСПЕКТ
}

Воинов А.П., д.т.н., профессор, ORCID: 0000-0001-7548-4212

Элькин Ю.Г., к.Т.н., доцент, Одесская государственная академия строительства и архитектуры yrik29@gmail.com, ORCID: 0000-0001-7677-377X

\begin{abstract}
Аннотация. Численность населения Земли растет с ускорением. Его потребности растут. Интенсивно развивается производство. Уровень его энергоэффективности невысок. Усиливается вредное воздействие производства на окружающую среду, особенно влияние энергетики, которая успешно развивается, независимо от условий в государстве. Перед человечеством встала проблема защиты и спасения природной среды и людей от вредного влияния производства, прежде всего, от нарастающего влияния энергетики. Целью и задачами проблемы является анализ существующей экологической обстановки под влиянием мировой энергетики и путей решения стоящих перед ней задач. В объектах энергетики на органическом топливе наибольший ущерб окружающей среде наносят котельные установки. Структура топливно-энергетического баланса энергетики Украины является сложной. В недрах Украины 95\% энергии находится в твердом топливе. В топливном балансе доля весьма дорогого импортного жидкого и газообразного топлива очень высока; она усложняет экономическую обстановку в энергетике и в государстве в целом. Сформировалась сложная проблема нормализации структуры топливного баланса отечественной энергетики. Парк действующих котлов изношен, требует немедленного полного обновления. Это также сложная проблема: нет развитого собственного котлостроения, недостаточны имеющиеся ресурсы, нет запаса времени. Проблема спасения природной среды обеспокоила мировую общественность. Были приняты важные решения Киотского протокола и Парижского совещания по вопросам климата. Стремление к повышению экологичности и энергоэффективности применяемых технологий обусловили разработку концепции и программы энергосбережения, как ключевого направления развития современного производства. В Украине программу энергосбережения приняли в 1994 году. Выполнение программы энергосбережения позволяет сочетать энергоэффективность производства с экологичностью. Тематика перспективных исследований в области мировой энергетики должна быть ориентирована на обеспечение задач программы энергосбережения и повышения эффективности природоохранной деятельности общества.
\end{abstract}

Ключевые слова: энергосбережение, энергоэффективность, энергетика, экологичность, защита природной среды. 